\title{
SEJARAH KESENIAN WAYANG TIMPLONG KABUPATEN NGANJUK
}

\author{
Anjar Mukti Wibowo \& Prisqa Putra Ardany*
}

\begin{abstract}
Abstrak
Penelitian ini bertujuan untuk mengungkap Sejarah Kesenian wayang Timplong Kabupaten Nganjuk. Penelitian ini dilakukan selama 4 bulan yaitu bulan Februari sampai Juli. Adapun bentuk penelitian ini merupakan pendekatan kualitatif. yang menggambarkan, berbagai situasi, atau berbagai fenomena realitas sosial yang ada di masyarakat. Jenis penelitian ini adalah penelitian deskriptif kualitatif. Sumber data yang dipakai yakni sumber data primer dan sumber data Sekunder. Teknik pengambilan data yaitu dengan menggunakan metode observasi, wawancara dan dokumentasi. Validasi yang dipergunakan untuk mengkuji kebenaran data yaitu menggunakan Trianggulasi sumber. Analisis data yang digunakan adalah analisis data model interaktif Miles dan Huberman yang didalamnya terdapat tiga tahapan yaitu melalui proses reduksi data, sajian data dan verifikasi data Berdasarkan hasil penelitian dapat diketahui bahwa Sejarah kesenian wayang Timplong di Kabupaten Nganjuk berasal dari Desa jetis Kecamatan Pace yang di ciptakan oleh Mbah bancol pada tahun 1910 dikarenakan kegemaran mbah Bancol masa kecil senang menonton pertunjukkan kesenian wayang Klithik yang berinisiatif membuat wayang baru yang berbeda dengan wayang lainnya dan semata mata untuk hiburan. Keahlian mendalang mbah Bancol diturunkan kepada putranya Ki Karto Guno hingga Ki Tawar Perkembangannya proses pewarisan mendalang wayang Timplong bukan lagi dari garis keturunan, yang mengakibatkan banyak bermunculan dalang-dalang wayang Timplong yang berasal dari berbagai daerah di Kabupaten Nganjuk luar Desa Jetis. Pada awalnya kesenian wayang Timplong dipentaskan sebagai sarana hiburan namun kini menggalami perubahan kesenian wayang Timplong lebih banyak dipentaskan sebagai sarana ritual upacara seperti ruwatan dan bersih desa. Pada tahun 2005 salah satu dalang wayang Timplong di Kabupaten Nganjuk mendapatkan penghargaan dari Gubernur Jawa Timur Imam Utomo sebagai apresiasi seniman kesenian Tradisional. Pada saat ini kesenian wayang Timplong tidak hanya dipentaskan di daerah Nganjuk saja tapi di luar Nganjuk dalam acara pentas seni untuk lebih mengenalkan kesenian wayang Timplong.
\end{abstract}

\section{Kata kunci Kesenian, Wayang}

\section{Pendahuluan}

Bangsa Indonesia adalah bangsa yang memiliki budaya yang beragam variasi baik suku, budaya, tradisi dan kesenian dari berbagai daerah di nusantara. Dalam sejarah perkembangannya, Bangsa Indonesia pernah mencapai masa kejayaan pada masa kerajaan, dengan berbagai seni dan budaya yang menyertainya hingga sekarang ini masih sangat dikagumi dan dapat kita banggakan. Karya tersebut merupakan hasil dari perwujudan akal, budi, dan pemikiran para penggawa seni yang tidak ternilai harganya, yang dijadikan sebagai warisan budaya bangsa. Salah satu warisan budaya Bangsa Indonesia yang terkenal dan diakui oleh Unesco adalah Wayang (Soetarno dan Sarwanto, 2010: 3).

Kesenian Wayang tersebar hampir diseluruh pelosok daerah di Indonesia, seperti Sumatera, Jawa, Bali, Lombok, Kalimantan dan lainnya (Sumukti Tuti,

* Anjar Mukti Wibowo adalah Dosen Pendidikan Sejarah IKIP PGRI MADIUN

* Prisqa Putra Ardany adalah mahasiswa Pendidikan Sejarah IKIP PGRI MADIUN 
2005: 22). Wayang-wayang tersebut tentunya memiliki kekhasan tertentu dan keunikan yang disesuaikan dengan kultur budaya setempat. Lebih dari 100 ragam jenis wayang yang terdapat diseluruh Indonesia. Wayang tersebut bersifat adaptif dan demokrasi, yang kemudian mengalami perkembangan dan berintergrasi dengan budaya lokal. Seiring berkembangnya jaman, baik bentuk variasi, dan secara pergelaran wayang itu sendiri mengalami perubahan sedikit demi sedikit agar menarik dan dapat dinikmati oleh semua kalangan khususnya dipulau Jawa dan Bali (Rifan Ali, 2010: 9).

Anderson dan Woro Aryadini (dalam Ardian Kresna, 2012: 22) Mengemukakan bahwa wayang adalah unsur terpenting dalam kebudayaan jawa, yaitu sebagai Compelling religius mythology, yang berarti bahwa cerita-cerita dalam pewayangan mampu menyatukan masyarakat Jawa secara menyeluruh, meliputi daerah geografi Jawa dan semua golongan sosial masyarakat Jawa. Wayang juga dianggap sebagai alat pemelihara dan penyebaran kebudayaan Jawa.

Mungkin, jarang ada kesenian lain didunia yang panjang pergelaranya menyamai wayang di Jawa, memakan waktu sewengi natas (semalam suntuk). Karena itulah, dapat dibayangkan betapa berat kerja maupun para niyaga (penabuh gamelan) serta warangga (penambang dalam pargelaran wayang) yang mendukung pargelaran tadi mulai talu (dimulai pargelaran wayang) sampai tancep kayon (selesainya pergelaran menjelang subuh yang ditandai dengan dalang menancapkan gunungan tegak ditengahtengah kelir (Imam Budhi Santoso (2012: 209-210).

Salah satu daerah yang memiliki potensi seni wayang adalah Nganjuk di Provinsi Jawa Timur. Kesenian Wayang Timplong dari Kabupaten Nganjuk kurang begitu populer di kalangan masyarakat, dikarenakan kalah bersaing dengan Wayang kulit Purwa yang berasal dari Jawa Tengah, selain itu masyarakat bila memiliki acara hajatan pernikahan, kitanan atau acara lainnya memberikan hiburan pada tamunya berupa orkes melayu, ataupun hiburan yang lain .yang menyebabkan kesenian Wayang Timplong terpinggirkan akibatnya banyak masyarakat kurang tahu mengenai kesenian tersebut. Padahal kesenian Wayang itu sendiri muncul pada acara-acara tradisi bersih desa dan acara besar lainya di Nganjuk seperti saat gelar budaya untuk memperingati hari jadi Nganjuk. Kesenian Wayang Timplong diacara tersebut bersama dengan kesenian-kesenian tradisional Nganjuk lainya seperti Tayub dan Pogokan.

Sebagai kesenian tradisional, Wayang Timplong dewasa ini mengalami kendala terhadap perkembanganya. Kesenian Wayang Timplong saat ini kurang begitu digemari oleh masyarakat Nganjuk. Hal tersebut di buktikan kurangnya masyarakat 
di Nganjuk untuk menggeluti kesenian ini. Dibuktikan dengan Paguyuban Wayang Timplong pimpinan Pak Djikan yang beranggotakan rata-rata orang tua (dengan usia sebagian besar 55-an), Masyarakat kurang tertarik dengan Wayang Timplong ini. Hal tersebut dikarenakan dalang, penabuh gamelan serta sinden sudah berumur tua, dan masyarakat sedikit yang mau mempelajari kesenian Wayang Timplong sebagai pelestarianya. Sedangkan generasi muda cenderung menyukai kesenian yang sifatnya baru sesuai dengan pola pikir masyarakat yang berubah modern. Generasi muda saat ini justru meninggalkan, kebudayaan-kebudayaan warisan leluhur sehingga budaya kita semakin tergerus Globalisasi yang melanda Indonesia. Globalisasi dengan segala mekanismenya telah membukakan pintu yang sangat luas bagi generasi muda Indonesia untuk memandang dunia, memilih, mengambil, dan menginginkan cara-cara hidup yang dipandang sesuai (Bambang dan Iwan, 2009: 181).

Generasi muda sebagai elemen penting dalam melestarikan kesenian khas daerah, lebih memilih untuk menampilkan dan menggunakan kesenian asing dari pada kesenian tradisional yang berasal dari daerahnya sendiri. Pada umumnya mereka merasa gengsi dan malu apa bila mempertahankan dan menggunakan kesenian tradisional, karena dianggap kuno dan ketinggalan jaman. Tanpa mereka sadari sesungguhnya kesenian tradisional atau kebudayaan lokal merupakan jati diri bangsa karena mencerminkan segala aspek kehidupan yang berada didalamnya.

Dengan kata lain kesenian tradisional merupakan salah satu kekayaan yang sangat bernilai karena selain merupakan ciri khas dari suatu daerah juga menjadi lambang dari kepribadian suatu bangsa. Apabila permasalahan ini berlangsung terus menerus, maka akan sangat berpengaruh hal kelangsungan kebudayaan suatu bangsa. Jelas masyarakat tidak lagi mewarisi nilai-nilai budaya leluhur, dan tidak memiliki jati diri.

Meskipun kesenian Wayang Timplong sering dipentaskan namun banyak masyarakat Nganjuk kurang mengetahui kesenian tersebut. Tak lain dibuktikan pada saat digelar budaya Tradisi Sedekah Bumi di Desa Sukomoro Kabupaten Nganjuk, pada 25 Oktober 2013 pada acara tersebut ditampilkan Kesenian wayang Timplong dengan dalang Pak Djikan dari Jetis. Namun masyarakat bertanya mengenai wayang tersebut. Kebanyakan masyarakat kurang mengetahui sejarah dan fungsi digelarnya pertunjukan wayang Timplong di Nganjuk. Untuk itu peneliti tertarik untuk melakukan penelitian lebih lanjut

\section{Tujuan dan Manfaat Penelitian}

Tujuan Penelitian ini untuk Mengungkap Sejarah kesenian Wayang Timplong Kabupaten Nganjuk (1910-2013). 
Peneletian ini diharapkan dapat bermanfaat bagi berbagai pihak diantaranya:

1. Bagi Program Studi pendidikan Sejarah FPIPS IKIP PGRI Madiun, hasil penelitian ini dapat berguna sebagai literatur kajian sejarah lokal untuk penelitian lebih lanjut.

2. Bagi Seniman wayang Timplong untuk menambah kreatifitas para seniman daerah Kabupaten Nganjuk dalam mengembangkan kesenian daerah.

3. Bagi Pemerintah Kabupaten Nganjuk, Pemerintahan dapat melihat keadaan yang ada dimasyarakat, sehingga dapat memberikan kebijakan terkait dengan pembinaan, pelestarian dan pengembangan kesenian tradisional daerah.

\section{Tinjauan Pustaka}

\section{A. Kesenian}

\section{Sejarah Kesenian}

Kesenian berasal dari kata seni mendapatkan imbuhan dari akiran an. Seni berarti keahlian membuat karya yang bermutu (dilihat dari segi kehalusannya.keindahannya, dsb) Karya yang diciptakan dengan keahlian yang luar biasa, seperti tari, lukisan ukiran menurut (Tim penyusun kamus pusat pembinaan dan pengembangan bahasa, Kamus Besar Bahasa Indonesia 1999 : 915).

Seni mendapat padanan kata techne (Yunani), ars (latin) kuns (jerman) dan art Bahasa Inggris. kesemuanya mempunyai pengertian yang sama yakni ketrampilan dan kemampuan. Ketrampilan dan kemampuan ini dikaitkan dengan tujuan seni misal estetis (keindahan), etis dan nilai praktis (Edy Tri S, 2005: 1).

Kapan dan di mana seni muncul pertama kali didunia nampaknya sulit untuk ditentukan. Edy Tri S (2005:5) Membagi seni menjadi beberapa masa antara lain : Seni Primitif, tujuanya peciptaanya berhubungan dengan kebutuhan dalam upacara upacaraupacara kepercayaan bentuknya abstrak dan simbolik.

Perkembangan selanjutnya masa klasik. Bicara dengan tentang, seni klasik acuanya cenderung kepada Yunani klasik. Gaya Yunani klasik mendasarkan pada balence, harmonisasi stabilitas dan selalu menggunakan ukuran matematis dalam segala arsiteknya. Selajutnya kesenian berkembang keseluruh dunia diawali pada abad ke 19 kemudian dianggap sebagai awal kelahiran seni modern. Dan pada akhirnya munculah berbagai aliran seni diantara neo klasikisme, romantisme dan lain lain. Dan ditahun berikutnya yaitu pada abad ke 20 muncul aliran seni yang lebih banyak lagi hingga saat ini.

Berdasarkan Ensiklopedi Tari (1980: iii) "Kesenian tidak lebih dari perwujudan dan nilai-nilai yang menjadi pedoman bagi pola tingkah laku anggota masyarakat pendukungnya". Pendapat senada disampaikan Nooryan Bahari (2008: 45) Bahwa kesenian merupakan 
unsur pengikat yang mempersatukan pedoman-pedoman bertindak yang berbeda menjadi suatu desaian yang utuh, menyeluruh dan operasional serta dapat diterima sebagai suatu yang bernilai.

Kesenian mengacu pada nilai keindahan (estetika) yang berasal dari ekspresi hasrat manusia akan keindahan yang dinikmati dengan mata ataupun telingga menurut ungkapan (Beny Kurniawan 2012: 114). Pendapat senada juga diungkapkan Bagoes P. Wiryamartono (2001: 136) Seni pada dasarnya bukanlah barang hasil produksi dan reproduksi alam, namun karya tangan manusia, maka seni memiliki daya-daya artifisial. Seni berkapasitas tidak alami dalam arti dibuat dan dimaksudkan untuk manusia dan kehidupanya. Harsojo (1982: 260) mengutarakan bahwa kesenian merupakan faktor yang amat esensiil untuk integrasi, dan kreativitas kulturil, sosial, maupun individuil.

Berdasarkan pengertian di atas dapat diperoleh suatu kesimpulan kesenian adalah suatu hasil pemikiran manusia yang dapat memberikan suatu keindahan bagi penikmatnya. Suatu kesenian akan tumbuh dan berkembang dikalangan masyarakat apabila masyarakat mau menerima kesenian tersebut. Untuk bisa diterima ditengahtengah kalangan masyarakat tentu sebuah kesenian itu harus bisa mewakili dari budaya atau pemikiran masyarakatnya.

\section{Fungsi Seni}

Manusia menciptakan suatu barang atau benda karena adanya keperluan dari penciptaan tersebut. Begitu juga dengan seni Edi Tri Sulityo (2005: 3-4) Mengungkapkan, seni dibagi menjadi tiga fungsi sebagai berikut :

a. Fungsi personal seni

Seniman-seniman pada abad modernini ekspresi yang berkaitan dengan fungsi personal seni sangtlah menonjol.

b. Fungsi sosial seni

Selama karya seni itu diciptakan kemudian disuguhkan atau dipamerkan untuk orang lain, maka dari situlah fungsi sosial seni akan hadir.

c. Fungsi Fisik Seni

Telaah karya seni yang paling tepat adalah pada hasil karya seni rupa. Sebab lewat hasil karya ini fungsi fisik seni akan dapat diwujudkan.

\section{Sifat-Sifat Seni}

Sifat- sifat seni menurut Edi Tri Sulistyo (2005: 89) adalah sebagai berikut :

a. Audio

Maksudnya hasil cipta seni yang mempunyai sifat dapat didengar..

b. Visual

Hasil cipta seni yang penghayatannya dengan menggunakan indera pengliahatan. 
c. Audio-Visual

Gabungan antara karya seni yang mempunyai sifat dapat didengar dan dibaca atau dilihat sekaligus

$$
\text { Berdasarkan pernyataan di }
$$

atas maka disimpulkan bahwa sifat seni ada tiga yaitu audio, visual dan audio visual.

\section{Jenis-jenis Fungsi Seni}

Nooryan Bahari (2008: 51-59) menyebutkan bahwa secara garis besar, kesenian dibagi menjadi beberapa jenis, sebagai berikut :

1. Seni Rupa

Suatu wujud hasil karya manusia yang diterima dengan indera penglihatan, dan secara garis besar dibagi menjadi seni murni dan seni terap.

2. Seni Musik

Seni yang diterima melalui indera pendengaran. Rangkaian bunyi yang didengar memberikan rasa indah.

3. Seni Tari

Seni yang diserap melalui indera pengelihatan, dimana keindahannya dapat dinikmati dari gerakan-gerakan tubuh, terutama dan gerakkan kaki dan tangan, dengan ritme-ritme teratur, yang diiringi irama musik yang diserap melalui indera pendengaran.

4. Seni Drama (Theater)

Seni pertunjukkan audio visual karena dapat dicerap melalui indera pengelihatan dan pendengaran. Dalam seni drama atau teater, kehadiran penonton sama pentingnya dengan pemain diatas panggung.

5. Seni Sastra

Seni sastra adalah seni yang ditekankan kepada tulisan melalui rangkaian susunan bahasa dan dapat dikemukakan melalui lisan untuk didengarkan maupun, maupun tulisan yang dapat dibaca.

Suatu karya seni merupakan ungkapan ekspresi senimannya. Oleh karena itu, pada karya seni selalu masih tinggal tersembunyi subjektivitas senimannya. Ekspresi seni berbeda dengan ungkapan emosional atau gejalagejala perasaan. Ungkapan emosional dapat terlihat langsung pada seseorang, sedangkan ekspresi seni hanya dapat didekati dengan kehalusan komunikasi yang ditularkan lewat kesan-kesan yang disampaikan melalui simbol-simbol (Juju Masunah dan Tati Narwati, 2003: 159). Pendapat lain diutarakan oleh Rohiman Notowidagdo (2002: 88) Sesuatu hasil seni dapat dikatakan indah apabila rangkaian dari bagian-bagiannya merupakan suatu susunan yang lengkap dan merupakan keutuhan, yang mampu menimbulkan kenikmatan.

\section{B. Seni Tradisional}

\section{Pengertian Seni Tradisional}

Menurut Ayu Sutarto (2004: 1) Mengatakan bahwa kesenian tradisional 
juga disebut kesenian rakyat yang mempunyai ciri-ciri tertentu terkait dengan wewaton (dasar pertunjukan). paugeran (aturan pertunjukan) dan pakem (bakuan dalam setiap pertunjukannya). Ketiga elemen tersebut merupakan rujukan utama yang selama ini dipegang teguh oleh para pewaris aktifnya dan telah menjadi konvensi dalam setiap pertunjukan seni tradisi.

Menurut Juju Masunah dan Tati Narawati (2003: 131) Kesenian tradisional adalah suatu bentuk seni yang bersumber dan berakar serta telah dirasakan sebagai milik sendiri oleh masyarakat dan lingkungannya. Hal serupa juga diungkapkan oleh Oka A. Yoety bahwa kesenian tradisional adalah kesenian yang sejak lama turun-temurun telah hidup dan berkembang pada suatu daerah tertentu. Kesenian tradisional semacam ini merupakan senibudaya bangsa yang telah banyak menarik wisata- wisatawan untuk berkenjung ke suatu daerah tujuan wisata tertentu.

Dari perngetian di atas maka dapat ditarik simpulan bahwa kesenian tradisional adalah merupakan keaneragaman budaya yang telah menyatu menjadian bagian hidup masyarakat yang dilestarikan hingga kini. Kesenian tradisional merupakan karya seni yang dikagumi masyarakat karena mempunyai keunikan yang berbeda-beda yang didalamnya juga terkandung kearifan lokal.

Wayang Timplong merupakan salah satu kesenian tradisional yang menjadi warisan budaya yang didalamnya menggandung nilai kehidupan dan pandangan hidup masyarakat. Wayang Timplong yang merupakan kesenian tradisonal ini telah menjadi bagian dari kehidupan masyarakat Nganjuk sebagai kesenian yang dipentaskan sebagai sarana hiburan dan sarana ritual yang dilakukan tiap tahunnya.

\section{Ciri-ciri Seni Tradisional}

Kesenian tradisonalyang dalam kajian budaya juga disebut sebagai kesenian rakyat mempunyai ciri-ciri tertentu yang terkait dengan weweton (Seni pertunjukan), panugeran (aturan pertunjukkan), ketiga element tersebut merupakan rujukan utama yang selama ini dipegang teguh oleh para pewaris aktifnya, dan telah menjadi konvensi dalam setiap pertunjukkan seni tradisi. Konvensi seperti ini, oleh para pewaris aktif, kadang-kadang diperlukan sebagai harga matikarena disamping mmperkuat ciri dan citra produk kesenian, terjadinya konvensi yang dijadikan wahana untuk merespon selera kebutuhan pasar di anggap sebagai langkah merusak kemurnian kesenian Tradisional (Ayu Sutarto, 2004: 01). Kesenian Tradisional yang memiliki pengaruh dominan 
terhadap perkembangan budaya bangsa adalah kesenian yang mempunyai kebanggan daerah (masyarakat pemilik atau pendukungnya).

\section{Wayang}

\section{Pengertian Wayang}

Wayang adalah suatu jenis pertunjukkan teater yang khas di Indonesia, terdapat pada berbagai suku bangsa (Jawa, Bali, Sasak, Sunda, Banjar), dan mempunyai sejumlah varian bentuk ungkapan, namun semuanya ditandai oleh kesamaan ciri teknis, yaitu tokoh tokoh cerita dibuat dalam bentuk peraga, berupa boneka pipih atau tiga dimensi dan peraga-peraga itu dimainkan oleh seorang dalang (Edy Sedyawati, dkk 2009: 49). Pendapat lain diutarakan oleh Hery Lisbijanto (2013: 1) Wayang adalah jenis seni pertunjukkan yang mengisahkan seorang tokoh atau kerajaan dalam dunia pewayangan.Wayang berasal dari kata Ma Hyang yang berarti kepada roh spritual, dewa atau Tuhan Yang Maha Esa.

Wayang sebagai seni pertunjukkan kebudayaan Jawa sering di artikan sebagai "bayangan" atau samar-samar yang dapat bergerak sesuai lakon yang dihidupkan oleh seorang dalang. Bayang itu juga dipahami sebagai gambaran perwatakan dan karakter manusia sebagai gambaran kehidupan berdasarkan isi cerita. Model wayang di Jawa yang terkenal wayang kulit Purwa (Andrian Kresna, 2012: 21). Kesenian wayang merupakan sisa-sia upacara keagamaan orang Jawa. Dulu masayarakat Indonesia banyak yang memeluk kepercayaan animisme dan dinamisme. Dalam kepercayaan ini, diyakini bahwa roh orang yang meninggal masih tetap hidup dan semua benda adalah bernyawa dan memiliki kekuataan.Sehingga mereka tetap dipuja dan dimintai pertolongan (Ali Rifan, 2010: 10).

Istilah wayang dalam kamus besar Bahasa Indonesia dapat di artikan :

a) Boneka tiruan orang yang terbuat dari pahatan kulit atau kayu dan sebagainya yang dapat dimanfaatkan untuk memerankan tokoh dalam pertunjukkan drama tradisional,biasanya dimainkan oleh seseorang yang disebut dalang.

b) Pertunjukkan wayang.

c) Bayang bayang.

Pengertian Wayang menurut Bausastra Jawi (Yogyakarta Balai Pustaka, 2002) adalah Bentuk atau rupa yang terjadi disebabkan dari barang yang terkena sorot dan Perwujudan orang atau barang lainya yang dibuat dari kulit (J Syahban Yasasusastra, 2011: 1).

\section{Sejarah Wayang}

Mengenai kelahiran budaya wayang menurut Ir Sri Mulyo ( dalam Bendung Layung K, 2011: 1) Mengatakan dalam bukunya Simbolis dan mistikisme dalam wayang (1979) memperkirakan wayang sudah ada sejak zaman Neolithikum, yakni kira-kira tahun 1500 
tahun sebelum masehi. Pendapat itu didasarkan atas tulisan Robert Vor Heine- geldern Ph.D, Prehistoric Research in the Netherland Indie (1945).

Dalam disertasinya yang berjudul Bijdrage tot de kennis van het Javaansche Toneel, (1897 di Leiden), ahli sejarah kebudayaan Belanda Dr. G.A.J Hazeau menunjukkan keyakinan bahwa wayang merupakan pertunjukkan asli Jawa. Pengertian wayang wayang dalam disertasi Dr G.A.J Hasae adalah walulang inukir ( kulit yang diukir) yang dapat dilihat bayanganya. Asal usul Wayang ada 3 versi

(Bendung Layung K, 2011: 2-3) pertama, pendapat yang menyatakan bahwa wayang berasal dan lahir pertama kali di pulau Jawa. Pendapat ini selain dianut dan dikemukakan oleh para peneliti barat diantaranya sarjana barat yang termasuk kelompok ini adalah Hazaeau dan para pakar indonesia seperti K.P.A Kusumadi laga, Ranggawarsita, Suroto, Sri Mulyono dan lain- lain.

Kedua ada dugaan wayang berasal dari India, yang dibawa dengan agama Hindu ke Indonesia. Pengamat keyakinan ini antara lain Dr. W.Rassers dan Dr.N.J Krom. Sebagaian besar kelompok ini adalah sarjana Inggris, negeri eropa yang pernah menjajah India. Ketiga ada peneliti dan penulis buku lainya yang mengatakan bahwa wayang berasal dari
Cina. Dalam buku Chineeseche Brauche Und Spiele in Europa, dimana Prof G. Schel menulis,bahwa dalam kebudayaan Cina Kuno terdapat pargelaran semacam wayang. Ini didiukung pada pemerintahan Kaizar $\mathrm{Wu} \mathrm{Ti}$, sekitar tahun 140 sebelum masehi, ada pertunjukkan bayang-bayang semacam wayang. Kemudian pertunjukkan ini menyebar ke India baru kemudian dari India dibawa ke Indonesia.

Kesimpulan bahwa wayang mempunyai banyak kesamaan antara wayang satu dengan wayang lain, yang berasal dari berbagai negara di Asia yang membedakan hanyalah bentuk tampilan wayang, istilah wayang, bahasa dan cerita-ceritanya bersumber dari Ramayana dan Maha barata.

Budaya wayang diperkiran sudah masuk setidaknya pada zaman pemerintahan raja Airlangga, Raja Kahuripan (976 - 1012), yakni ketika kerajaan di Jawa Timur sedang makmurmakmurnya. Dalam metodologi Jawa, sering bercerita tentang Maha barata dan Ramayana yang dimainkan oleh para dalang atau scenario wayang.

Menurut Adrian Krisna (2012: 27) wayang yang bersumber pada Mahabarata memiliki gambaran sifatsifat manusia yang komplek artinya, artinya lengkap dan menyeluruh, yang hampir tiap manusia mengalami kasus yang dialami pula dalam cerita tersebut. 
Cerita utama Mahabarata menampilkan dua buah kelompok dalam satu keturunan, yaitu Pandawa dan Kurawa yang saling bertentangan.Pandawa mewakili prilaku halus dan Kurawa mewakili prilaku kasar.

Cerita Ramayana dan Mahabrata yang asli berasal dari India, telah diterima dalam pargelaran wayang Indonesia sejak zaman Hindu hingga sekarang. Wayang seolah-olah identik dengan Ramayana dan Mahabarata. Namun perlu dimengerti bahwa Ramayana dan Mahabarata versi India itu sudah banyak berubah alur ceritanya; kalau Ramayana dan Mahabarata India merupakan cerita yang berbeda satu dengan yang lainnya, sedangkan di Indonesia menjadi satu kesatuan. Dalam seni wayang cerita Ramayana dan Mahabarata memiliki tokoh-tokoh wayang. Tokoh-tokoh ini mempunyai ratusan tokoh. Setiap tokoh memilik karakter-karakter tersendiri.

\section{Jenis-Jenis Wayang}

Soetarno dan Sarwanto (2010:3) Mengutarakan kesenian wayang terdapat bermacam macam wayang diantaranya : Wayang Kulit, Wayang Purwa, Wayang Parwa, Wayang Madya, Wayang Gedog Wayang Beber, Wayang Calonarang, Wayang Krucil, Wayang golek, Wayang Menak, Wayang, Wayang Klithik, Wayang Suket, Wayang Gung, Wayang Potehi, Wayang Orang. Dalam hal ini kesenian wayang Timplong termasuk dalam jenis wayang Klithik karena bahan dasar pembuatan wayang dari kayu.

\section{Jenis Lakon Wayang}

Soetarno dan Sarwanto (2010: 12) Menjelaskan Wayang dari zaman ke zaman wayang selalu mengalami perkembangan dan perubahan baik dalam bentuk, teknik permainya serta jenis lakon wayang sendiri terus berkembang hingga dapat digolongkan menjadi beberapa kreteria pagelaran (Pakem) yang akan menuntun para pemirsanya lebih memehami cerita wayang yang akan disajikan oleh dalang.

Dari Uraian diatas dapat disimpulkan bahwa pengertian kriteria cerita (pakem) adalah sumber lakon sebagai pedoman pelaksanaan teknik wayang yang yang akan disajikan.Lakon wayang setiap pargelaran wayang berbeda-berbeda, tergantung dalang dan waktu pelaksanaanya.

Isi cerita yang disampaikan oleh para dalang sangatlah penting artinya karena akan memberikan pengalaman jiwa yang mendalam. Pesan-pesan tersebut menyangkut nilai-nilai religius, moral kemanusiaan, keadilan, kesetian, kesetiakawanan sosial, dan patriotisme. Artinya dalang mampu menjawab tuntunan perkembangan zaman beserta kebutuhan masyarakatnya dengan 
menyajikan karya-karya lebih berkambang dan variatif dengan tetap berpegangan pada konsep etika dan estetika.

\section{Simbol Dalam pagelaran Wayang}

Layung Bendung Kuning (2011:

14-15) Mengutarakan Wayang bagi orang Jawa merupakan simbolisme pandangan-pandangan hidup orang Jawa mengenai hal hal kehidupan. Dalam wayang seolah-olah orang Jawa tidak hanya berhadapan dengan teori-teori umum tentang manusia, melainkan model-model hidup dan kelakuan manusia digambarkan secara konkrit. Pada hakikatnya seni pewayangan mengandung konsepsi yang dapat dipakai sebagai pedoman hidup, baik dalam sikap pandangan terhadap hakikat hidup, asal dan tujuan hidup, hubungan manusia dengan Tuhan, hubungan manusia dengan lingkungannya serta hubungan manusia Jawa dengan manusia lain.

Sementara itu Imam Budhi Santoso (2012: 210) Menjelaskan Kendati pargelaran Wayang tak ubahnya pementasan cerita dengan fitur boneka, namun potensinya memiliki nilai lebih dibandingkan kesenian lain. Karena dalang, tokoh yang ngudhal udhal piwulang (membongkar dan menyampaikan ajaran) mampu memberikan pencerahan,sekaligus menghibur. Melalui seluruh penampilannya nilai pesan wayang berhasil menyibakkan kegelapan malam dan merasuk kedalam hati sanubari orang jawa dari masa ke masa.

Sesuai dengan pakem pendalangan jawa, pargelaran wayang mengandung berbagai simbol kehidupan. Selain itu, pargelaran wayang juga mempunyai makna filsfat nilai nilai sosial budaya yang cukup tinggi.

\section{Metode Penelitian}

\section{A. Tempat Dan Waktu Penelitian}

Lokasi atau tempat penelitian ini Desa Jetis Kecamatan Pace Kabupaten Nganjuk. Di pilihnya desa Jetis dikarenakan terdapat kesenian tradional yaitu kesenian Wayang Timplong berasal dari desa tersebut dan kesenian tersebut mulai terpinggirkan sedangkan masyarakat di desa Jetis kecamatan Pace Kabupten Nganjuk, potret masyarakat desa Jetis merupakan masyarakat yang sudah berkembang. Waktu yang digunakan dalam penelitian adalah enam bulan dari bulan Februari sampai Bulan Juli tahun 2014.

\section{B. Pendekataan dan Jenis Penelitian}

Pendekataan dalam penelitian ini adalah penelitian Kualitatif. Penelitian kualitatif adalah suatu penelitian yang ditujukan untuk mendeskripsikan dan menganalisis fenomena, peristiwa, aktifitas sosial, sikap, kepercayaan, persepsi, pemikiran orang secara 
individual atau kelompok (Nana Syaodih 2011: 60). Sedangkan jenis penelitian yang digunakan Diskritif kualitatif.

Menurut Sutopo (2002: 35) penelitian deskriptif merupakan data yang dikumpulkan berupa kata-kata, gambar dan bukan angka-angka. Dengan demikian laporan penelitian akan berisi kutipan-kutipan data untuk memberi gambaran penyajian laporan tersebut.

\section{Sumber Data Penelitian}

Sumber data yang digunakan dalam penelitian ini berasal dari Data Primer dan Sekunder. Data primer dapat dijelaskan sebagai data murni yang diperoleh dari hasil penelitian lapangan secara langsung dan masih memerlukan pengolahan lebih lanjut, kemudian baru data itu memiliki makna atau arti (Muhammad Teguh, 1999: 122). Sumber pertama dari penelitian ini berupa hasil wawancara dari Dinas Kebudayaan, ketua paguyuban, Dalang wayang, Kepala Desa Jetis.

Data Sekunder adalah data yang diperoleh lewat pihak lain, tidak langsung diperoleh oleh penelitinya (Saifuddin Azwar, 2004: 91). Sumber data sekunder dipakai dalam penelitian ini berupa sumber-sumber pustaka yang diambil dari dokumen-dokumen atau arsip-arsip dari paguyaban Wayang Timplong serta bahan kepustakaan baik dari buku maupun jurnal ilmiah serta data lain yang relevan dengan topik penelitian

\section{Teknik Pengumpulan Data}

Teknik Pengumpulan data merupakan cara mengumpulkan data yang dibutuhkan untuk menjawab rumusan masalah. Penerapan teknik pengumpulan data dalam penelitian ini agar dapat menghasilkan data yang lengkap. Adapun teknik pengumpulan data adalah Observasi non partisipan, interview (Wawancara) terpimpin dan dokumen tertulis atau arsip.

\section{E. Teknik Keabsahan Data}

Teknik pengujian keabsahan data dalam penelitian ini menggunakan teknik trianggulasi. Trianggulasi adalah teknik pemeriksaan keabsahan data yang memanfaatkan sesuatu yang lain di luar ddata itu untuk keperluan pengecekan atau sebagai pembanding terhadap data itu (Meleong, 2012: 330).

Trianggulasi yang digunakan adalah trianggulasi Sumber. Trianggulasi sumber dilakukan dengan mengecek data yang telah diperoleh dari sumber data yang satu dengan sumber data yang lain, dalam hal ini yang diperoleh dari Dinas kebudayaan Nganjuk, Ketua paguyuban wayang Timplong, Dalang wayang Timplong dan dari Kepala Desa Jetis.

\section{F. Teknik Analisis Data}

Analisis data dalam penulisan ini menggunakan analisis interaktif tiga 
komponen. Tiga Komponen utama tersebut adalah (1) Reduksi Data, (2) Sajian Data, (3) penarikan kesimpulan atau Verifikasi ( Miles dan Huberman, 1992: 16-19).

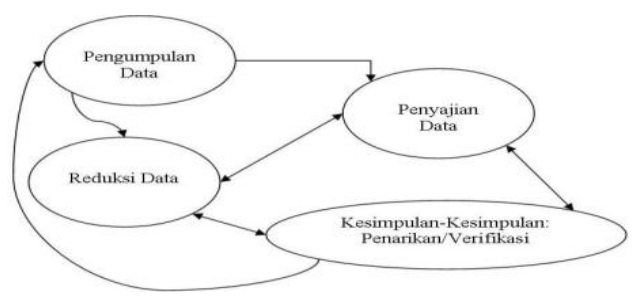

Bagan 3.2 (Analisis Kualitatif modelInteraktif Miles dan Huberman, 1992: 20).

\section{Hasil Penelitian}

\section{A. Gambaran Umum Desa Jetis}

\section{Keadaan Geografis}

Desa Jetis terletak di Kecamatan Pace Kabupaten Nganjuk. Secara geografis letaknya sangat strategis dan mudah dijangkau. Hal ini disebabkan jarak desa jetis dengan Kecamatan Pace hanya $5 \mathrm{Km}$, $10 \mathrm{Km}$ dari pusat pemerintahan Kabupaten Nganjuk dan 175 km ke ibu kota provinsi Jawa Timur.

Secara Administratif Desa Jetis di batasi oleh sebelah utara yaitu Desa Kecubung Kecamatan Pace, sebelah selatan Gemenggeng Kecamatan Pace,sebelah timur Desa Pace Wetan Kecamatan Pace, sebelah barat berbatasan Desa Kecubung Kecamatan Pace.

\section{Keadaan Demografi}

Luas keseluruhan wilayah Desa Jetis, memiliki luas wilayah kurang lebih sebesar 187.705 Ha. Jumlah penduduk Desa Jetis secara keseluruhan berjumlah 2.864 .

\section{B. Paparan Data}

\section{Asal Usul Kesenian Wayang Timplong}

Kesenian wayang Timplong berasal dari desa Jetis di ciptakan oleh mbah Bancol tahun 1910. Mbah Bancol pendatang berasal dari daerah Grobogan Jawa Tengah yang menetap di Desa Jetis, mbah Bancol semasa kecilya sangat menyukai wayang Krucil atau disebut wayang Klithik di wilayah Jawa Timur. Setiap ada pagelaran wayang Krucil di wilayah Grobogan, mbah Bancol selalu ingin melihatnya. Dari kebiasaan tersebut akhirnya tumbuh rasa menyenangi wayang Krucil dari sinilah mbah Bancol ingin menciptakan suatu kesenian wayang Krucil yang berbeda dengan yang lain

\section{Asal Penamaan Kesenian Wayang} Timplong

Timplong itu berasal dari suara gamelan penggiring wayang kayu, perpaduan antara bunyi gamelan kenong dan gamelan gambang yang terbuat dari bambu. Gamelan wayang Timplong sederhana, jika gamelan dipukul bunyi gamelan kenong dan gambang yang paling dominan bunyinya akhirnya dari kejauhan terdengar bunyi plong...plong . Dari itulah istilah Timplong muncul akhirnya menyebut wayang kayu jadi wayang Timplong.Selain disebut wayang Timplong juga disebut wayang Klithik di luar Nganjuk dikarenakan mengeluarkan bunyi klithik-klithik dari 
wayang tadi dimainkan atau di tata di saat pargelaran.

\section{Pementasan Kesenian Wayang Timplong.}

wayang Timplong dipentaskan di desa-desa daerah kabupaten Nganjuk awalnya digunakan sebagai sarana hiburan semata, karena zaman penjajahan belanda dan jepang masyarakat Nganjuk sulit menemukan hiburan.Sedangkan pada saat ini kebanyakan desa-desa dikabupaten Nganjuk mementaskan Kesenian wayang Timplong pada saat bersih desa ataupun ruwatan desa yang diadakan pada bulan Suro

\section{Karakteristik Wayang Timplong}

Wayang Timplong mirip dengan wayang kulit, namun terbuat dari kayu berbentuk pipih sehingga termasuk dalam jenis wayang Klitik atau wayang Krucil. Gamelan penggiring kesenian wayang Timplong tidak seperti dalam pagelaran wayang kulit, gamelan wayang Timplong lebih sederhana hanya terdiri dari, gendang, gambang, gong, dan kenong yang cukup sederhana namun cukup untuk menggiringi keseian Wayang Timplong. Dalam satu pagelaran wyang timplong terdapat kurang lebih 60 buah tokoh wayang terdiri dari beberapa tokoh, Binatang dan senjata

\section{Periodesasi Perkembangan Kesenian Wayang}

Perkembanganya kesenian wayang Timplong mengalami masa pasang surut dimasyarakat Nganjuk. Dari awal perkembanganya kesenian wayang Timplong dipentaskan untuk hiburan masyarakat, namun menggalami perubahan bergeser menjadi kesenian di acara upacara bersih desa atau ruwatan. Kesenian wayang Timplong mengalami masa kejayaan pada tahun 1980, pada saat itu wayang Timplong sering dipentaskan masyarakat dalam acara hajatan masyarakat seperti pernikahan, sunatan dan lain lain. Sedangkan tahun 1990 sampai saat ini kesenian wayang Timplong kalah bersaing dengan kesenian modern yang mengakibatkan kesenian tradisonal mulai jarang di pentaskan di masyarakat dan dipentaskan pada saat warga desa mengadakan bersih desa atau ruwatan setahun sekali.

\section{Faktor- Faktor yang mempengaruhi Perkembangan Wayang}

Kesenian Tradisional lainnya yang ada di daerah Nganjuk, kesenian wayang Timplongperkembanganya memprihatinkan nasibnya kalah bersaing dengan kesenian modern yang banyak di sukai masyarakat yang mengakibat kesenian Timplong jarang ditampil dimasyarakat dan kurang berkembang dan sepinya peminat remaja untuk menekuninya. Faktor yang mempengaruhi perkembangan kesenian wayang Timplong di kabupaten Nganjuk antara lain 1) Kebiasaan masyarakat, 2) Wayang Kulit, 3) Pemerintahan, 4) paguyuban dan 5) Seniman dan masyarakat. 


\section{Pembahasan}

\section{A. Sejarah Kesenian Wayang Timplong di Kabupaten Nganjuk}

Sejarah secara umum dapat diartikan cerita perubahan-perubahan, peristiwaperistiwa atau kejadian masa lampau yang telah di beri tafsir atau alasan dan dikaitkan sehingga membentuk suatu pengertian yang lengkap (Rustam E Tamburaka 1999: 2). Sejarah lahirnya Kesenian wayang Timplong diawali dari tahun sekitar 1910, pada saat itu di daerah Nganjuk sulit menemukan hiburan untuk masyarakat pribumi, karena wilayah Nganjuk sedang di kuasai oleh penjajah bangsa Belanda.

Sejarah kemunculan kesenian wayang Timplong atas dasar inisiatif dari Mbah Bancol yang bertempat tinggal didesa Jetis yang ingin menciptakan suatu hiburan berbeda dengan yang ada saat itu, dahulu ketika masih kecil menyukai wayang Klithik. Wiwien Widyawati R (2010: 916) Menggungkapkan Wayang Klithik adalah kalotakan (mengeluarkan bunyi kayu beradu).Wayang tersebut terbuat dari kayu di buat oleh Kanjeng Sunan Kudus jumlahnya hanya 70 buah dan memakai cerita lakon babad Padjajaran sampai dengan majapahit berakhir. Sebagai pencipta sekaligus dalang pertama Wayang Timplong, mbah Bancol sangat menyukainya wayang Klithik. Setiap pagelaran wayang Klithik didaerahnya ia selalu ingin melihat, dari kebiasaan tersebut akhirnya tumbuh rasa menyenangi, dari sinilah Mbah Bancol berupaya menciptakan kesenian wayang Klithik yang berbeda dengan yang dilihatnya.

Seniman Wayang Timplong menyakini adanya suatu mitos dalam awal pembuatan wayang. Abd. Rahmad Hamid dan Muhammad saleh Madjid (2011: 09) Mengungkapkan mitos adalah cerita tentang masa lalu, sepertinya hal juga sejarah, namun fondasi waktu tidak jelas dan alur pikiranya tidak rasional (manusia di gambarkan dengan sifat-sifat yang tidak lazim atau manusiawi). Mitos yang berkembang pada seniman wayang Timplong bahwa dulu melalui sebuah proses yang cenderung mistis. Awalnya Mbah Bancol tengah membelah sebatang pohon pohon waru untuk kayu bakar. Namun anehnya pada satu belahan kayu itu terlihat sebentuk gambar yang mirip wayang.

Selanjutnya seperti mendapat tuntunan gaib, Mbah Bancol selanjutnya memahat kayu itu dan mewujudkan bentuk gambar itu menjadi sebuah wayang. Dari satu wayang yang berhasil dibuat, itu mendorong Mbah Bancol untuk terus membuat wayang yang lain hingga akhirnya terbentuk seperangkat. Dan sebagai pelengkap, Mbah Bancol juga menyiapkan seperangkap gamelan sederhana sebagai pelengkap.

Terciptanya suatu karya seni tidak hanya bakat saja yang dibutuhkan. Edi Setiawati (1984: 29) bakat tiada lain 
hanyalah pembawaan sejak lahir, yang merupakan kemungkinan bagi orang yang bersangkutan untuk dapat lebih mudah, lebih cepat berhasil dalam menguasai suatu ketrampilan, apabila di usahakan mewujudkanya. Faktor yang pendukung lainya seperti kesempatan perkembangan, kemantapan profesi, kepekaan estetik dan juga ketrampilan juga diperlukan dalam penciptaan karya seni.

Meskipun bakat bukan merupakan faktor utama penciptaan karya seni namun faktor-faktor pendukung lainnya adalah dari segi kesempatan jelas terdapat karena pada saat itu Mbah Bancol ingin menciptakan wayang baru, yang tidak membutuhkan banyak biaya dan menghibur semua kalangan masyarakat. Selain itu ada juga potensi masyarakat dalam bidang seni dengan banyak masyarakat bisa bermain gamelan dan sedikitnya hiburan dimasyarakat secara tidak langsung potensi tersebut menjadikan suatu karya seni menjadi Populer. Kemantapan profesi yaitu orang akan menjadi dalam bidanganya sendiri yang menjadi pilihan dan kebanggannya.

Faktor penciptaan seni selanjutnya adalah faktor kepekaan estetik atau budaya tangkap yang kuat terhadap nilai-nilai keindahan dan memantulkan kembali kedalam kreasi perbuatan karya seni yang ada pada kesenian wayang Timplong yang diwujud dalam pementasan wayang, saat mendengarkan lagu penggiring wayang yang sangat sederhana dapat mengeluarkan suara yang enak didengarkan merupakan suatu unsur yang enak paling dominan, oleh karena itu gamelan penggiring wayang tersebut memiliki nilai-nilai keindahan.

Sedangkan ketrampilan perbuatan estetik merupakan pembawaan atau hasil latihan. Di lihat dari pementasanya wayang Timplong di kemas dengan kesederhanaan. Wayang Timplong cukup terbuat dari kayu, sedangkan penekanan tokoh wayang, wajah wayang di warnai dengan warna hitam dan putih yang dominan. Sementara itu pada bagian badan wayang ukirannya tidak terlalu rumit. Dan seluruh anngota pertunjukan yakni Dalang dan Niyaga menggunakan baju tradisional Jawa Tengah serta memakai Blangkon di kepala dan selipkan senjata keris dipinggang. Keserasian Dalang dan Niyaga dalam suatu pemtasaan tersebut muncul setelah berlatih dalam beberapa bulan.

Beberapa faktor yang di alami Mbah Bancol pada saat itu telah membawa dan mengarahkan untuk membuat dan mewujudkan suatu karya seni. Hal ini adalah dengan melihat situasi dan kondisi serta keseharian serta keseharian Mbah Bancol yang tidak bisa di pisahkan dari kesenian memungkinkan Mbah Bancol pada saat itu untuk menciptakan suatu kesenian yang pada saat ini dikenal dengan kesenian wayang Timplong.

Cerita yang di ambil dalam pementasan Kesenian wayang Timplong 
adalah cerita Panji mengisahkan mengenai kemelut yang terjadi saat raja Kediri dan keraajaan Jenggala bermaksud mengawinkan putera-puterinya dengan putra dari kerajaan Jenggala. Kerajaan Kediri dan kerajaan Jenggala pada awalnya berasal dari satu nenek moyang, yaitu raja Airlangga setelah raja Airlangga turun tahta dan menjadi pendeta, kerajaanya dibagi menjadi diwariskan kepada puteranya. Pada saat kerajaan Jenggala diperintah oleh raja Lembu Amiluhur, kerajaan Kediri diperintah oleh adik yang bernama Prabu Lembu Asmani.

Kedua saudara telah melakukan menjalin kesepakatan bahwa dikemudian hari bila mereka mempunyai anak akan dijodohkan untuk mempersatukan kembali dua kerajaan tersebut. Kebetulan raja Lembu Amilur mempunyai putera bernama Panji Asma Bangun. Sedangkan raja kediri mempunyai putri yang cantik bernama Putri Sekartaji. Niat baik kedua raja untuk menjodohkan puteranya tidak berjalan mulus. Banyak sekali cobaan dan godaan dan peristiwa-peristiwa yang berusaha menggagalkan perkawinan Raden Asma Bangun dengan Dewi sekartaji. Akan tetapi pada akhirnya semua rintangan dan godaan tersebut dapat di atasi.

Dalam perkembangan Kesenian wayang Timplong, Mbah Bancol sebagai pencipta sekaligus dalang pertama mewariskan keahlianya mendalang wayang Timplong kepada Darto Dono dan selanjutnya kemampuan mendalang di wariskan ke pada putranya Ki Karto Jiwul selanjutnya kesenian wayang Timplong dilanjutkan oleh putra dari ki Karto Jiwul yakni Ki Tawar. Kemudian seni mendalang Wayang Timplong diturunkan kepada $\mathrm{Ki}$ Maelan, Ki Talam serta Ki Djikan. Proses pewarisan mendhalang dari mbah Bancol hingga Ki Tawar merupakan berdasarkan garis keturunan, tetapi regenerasi dari ki Maelan hingga ki Djikan bukan lagi karena keturunan karena mereka pemain gamelan dari ki Tawar. Perkembangannya proses pewarisan mendalang Wayang Timplong bukan lagi dari garis keturunan, yang mengakibatkan banyak bermunculan dalang-dalang Wayang Timplong yang berasal dari berbagai daerah di Kabupaten Nganjuk luar Desa Jetis.

Sejak awal kemunculan kesenian Wayang Timplong yang diciptakan oleh mbah Bancol pada tahun 1910 kesenian wayang Timplong mengalami pasang surut dan menggalami perubahan dalam beberapa waktu. Hal tersebut dikarenakan perkembangan zaman sehingga menuntut suatu kesenian untuk menyesuaikan dengan perkembangan pola pikir masyarakatnya. Harus disadari bahwa setiap kemuncul periode kemunculan karya seni mempunyai standar atau kreteria masing-masing (Nooryan Bahari 2008: 177).

Dari tahun 1910-2013 telah terjadi dinamika perubahan dari kesenian wayang Timplong, mulai dari alat musiknya yang 
awalnya dari batok kelapa berubah menjadi seperangkat gamelan yang terdiri dari Gambang, gendhang kenong dan Gong. Sedangkan mulai tahun 2000 mulai adanya seorang sinden dalam pagelaran wayang, perubahan ini dikarenakan agar kesenian Wayang Timplong bertahan dalam gempuran kesenian Modern. Begitu pula dengan fungsi dipentaskan kesenian wayang Timplong awalnya kesenian wayang Timplong hanya semata mata untuk hiburan tetapi dengan perkembanganya zaman kesenian wayang Timplong juga mulai sebagi kesenian ritual. Pada tahun 2005 Salah satu dalang kesenian Wayang Timplong yakni ki Maelan mendapatkan penghargaan dari Gubernur Jawa Timur Imam Utomo sebagai apresiasi seniman kesenian Tradisional.

Keberadaan Kesenian wayang Timplong tidak lepas dari peran serta Masyarakat, selama masyarakat masih menganggap dan membutuhkan kesenian Wayang Timplong tetap lestari. Keberadaan Kesenian wayang Timplong pada saat ini rutin tampil pada saat bersih desa, ruwatan dan acara lainnya. Namun berkat kerja sama dengan pemerintahan selain tampil dalam acara di lingkup kabupaten Nganjuk Kesenian wayang Timplong juga berhasil mempromosikan dirinya diberbagai daerah lain seperti Surabaya dan Kediri untuk mewakili pertukaran kesenian daerah. Setiap tahunnya Kabupaten Nganjuk mengadakan festival gelar budaya pada saat perayaan hari jadi Kabupaten Soedarsono (1985: 267) festival dan lomba rupanya merupakan salah satu cara untuk merangsang usaha pelestarian dan pengembangan kebudayaan Tradisional.

Masyarakat Nganjuk menyakini disebut dengan Timplong karena ada hubungan dengan bunyi gamelan yang biasa dipergunakan untuk menggiring kesenian pada setiap pagelaran. Soertarno dan Sarwanto (2010: 44) mengungkapkan Gamelan adalah esembel musik jawa atau karawitan berlaras slendro dan pelog. Dalam gamelan pewayangan berlaras Selendro. Jumlah maupun jenis gamelan yang dipergunakan dalam wayang Timplong lebih sederhana bila dibandingkan gamelan wayang Kulit. Gamelan dalam wayang Timplong terdiri dari

1. Gendhang digunakan untuk mengatur cepat atau lambatnya irama lagu yang sedang dimainkan. Di pergunakan untu mengiring gerak wayang yang sedang dimainkan dalang.

2. Gambang yang dipergunakan dalam wayang Timplong berbeda dengan gembang wayang Kulit. Bila gamabang dalam wayang kulit bilanya terbuat dari kayu sedangkan pada wayang Timplong bilahnya terbuat dari bambu.

3. Gamelan gong terdiri dari satu buah berukan sedang dan dibunyikan secara berselang-seling dengan kenong.

4. Kenong dipergunakan sebagai pengisi selingan bergantian dengan selingan 
gong. Saat suara gamelan berbunyi suuara kenong dominan dalam kesenian wayang Timpong. Sehingga dari kejahuan gamelan wayang didengarkan secara seksama suara yang terdengar timplang...timplong.....

timpang...timplong. dari sinilah istilah wayang Timplong muncul dimasyarakat Nganjuk.

Keunikan latar belakang penamaan wayang Timplong berdasarkan bunyi suara gamelan yang mengiringnya patut mendapat apresiasi mengingat penamaan wayang didasarkan pada bunyi-bunyian gamelan yang menggiringi bukan bahan baku atauakarakter tokoh-tokoh wayangnya. Bunyi gamelan telah melekat dibenak masyarakat Nganjuk. Begitu halnya dengan kesenian Dongkrek yang berasal dari Kabupaten Madiun, dinamakan Seni Dongkrek karena bunyi yang dikeluarkan dari alat musik Dongkrek yang berbunyi “dong krek...krek..krek..”

\section{Penutup}

\section{A. Simpulan}

Berdasarkan penelitian yang dilakukan maka dapat di tarik kesimpulan bahwa sejarah kesenian wayang Timplong merupakan kesenian tradisional, yang berasal dari Desa Jetis Kecamatan Pace Kabupaten Nganjuk yang di ciptakan oleh Mbah bancol pada tahun 1910 dikarenakan kegemaran mbah Bancol masa kecil senang menonton pertunjukkan kesenian wayang Klithik yang berinisiatif membuat wayang baru yang berbeda dengan wayang lainnya dan semata mata untuk hiburan karena pada saat itu Daerah Nganjuk kesulitan menemukan hiburan dikarenakan di Jajah Belanda.

Penamaan wayang Timplong dikarenakan suara gamelan penggiring kesenian wayang terbuat dari bambu dan bila di pukul mengeluarkan bunyi plong....plong bila didengarkan karena bunyi bambu tersebut, akhirnya masyarakat menyebut dengan wayang Timplong.

Kesenian wayang Timplong dahulu dipentaskan untuk sarana hiburan namun karena perkembangan zaman, kesenian wayang Timplong lebih banyak dipentaskan dalam acara-acara bersih desa atau ritual tertentu didesa-desa daerah Nganjuk.

Kesenian wayang Timplong mempunya karakteristik sendiri Wayang terbuat dari jenis kayu Mentaos, serta bagian badan tidak ada ukiran seperti wayang kulit serta bagian tangan terbuat dari kulit sapi. Gamelan penggring wayang Timplong sangat sederhana yang merupakan ciri khas yakni Gambang, Kenong, Gendhang dan Gong. Jumlah wayang dalam pagelaran 70 buah terdiri dari tokoh wayang, binatang dan senjata.

Perkembangan kesenian tidak terlalu mengalami perubahan secara drastis, yang mengalami perubahan hanya gamelan penggiring kesenian wayang dan mulai ada sinden dalam pementasan wayang. Wayang Timplong mengalami keemasan pada saat 
tahun 1980 dan menggalami kemunduran tahun 1990 karena kalah bersaing dengan kesenian modern.

Seperti kesenian-kesenian tradisional nasib kesenian wayang Timplong kurang begitu berkembang dimasyarakat Nganjuk karena kalah bersaing dengan kesenian kesenian modern, tidak adanya remaja yang minat menggeluti kesenian tersebut dan kalah bersaing dengan kesenian Wayang kulit yang lebih populer dikalangan masyarakat.

\section{B. Saran}

\section{Masyarakat Desa Jetis Kecamatan}

\section{Pace Kabupaten Nganjuk}

Sebagai warisan leluhur, kesenian wayang Timplong terus dijaga dan dilestarikan. Menginggat kesenian Wayang Timplong selain peninggalan leluhur juga menggandung nilai filosofi kehidupan bagi masyarakat Desa Jetis khususnya dan masyarakat Nganjuk serta masyarakat Jawa.

\section{Pemerintahan Kabupaten Nganjuk}

Peneliti menaruh harapan besar kepada seluruh pihak dalam Kesenian Wayang Timplong supaya dilestarikan dan perhatian dari pemerintah yang saat ini diberikan supaya terus dikembangkan agar kedepannya bisa lebih baik lagi.

\section{Dinas Kebudayaan dan Pariwisata}

\section{Kabupaten Nganjuk}

Peneliti menaruh harapan besar kepada segenap elemen yang berperan dalam promosi budaya khususnya kepada pemerintah agar perhatian yang telah diberikan terus ditambah dan lebih sering di ikut sertakan dalam gelar budaya baik daerah maupun luar daerah.

\section{Seniman Wayang Timplong}

Peneliti menaruh harapan besar kepada seniman baik dalang maupun Niyaga terus melestarikan kesenian wayang Timplong ke semua masyarakat Nganjuk dan mendirikan Paguyuban seniman Wayang Timplong agar bisa kesenian berkembang dan eksis dimasyarakat.

\section{Program Pendidikan Sejarah FIPS}

\section{IKIP PGRI MADIUN}

Sebagai peninggalan sejarah kesenian Tradisional seperti wayang Timplong harus diperhatikan keberadanya untuk menambah wawasan dan kajian sejarah mengenai kesenian daerah lokal.

\section{Daftar Pustaka}

Abd Rahman Hamid dan Muhammad Saleh Masjid.2011 .Pengantar ilmu Sejarah.Yogjakarta : Penerbit Ombak

Adrian Krisna. 2012. Mengenal Wayang. Yogyakarta: Laksana

Ali Rif'an 2010. Bukuku Pintar Wayang Berkenalan Lebih Intim, Detail dan Mudah Dunia Wayang. Yogjakarta : Garailmu

Ayu Sutarto.2004. Menguak Pergumulan Antara Seni, Politik, Islam dan Indonesia Jember: Kompyyawisda 
Bagoes P.Wiryomartono 2001. Pijar-pijar Penyingkap Rasa Sebuah Wacana Seni dan Keindahan, dari Plato sampai Derrida. Jakarta: PT Gramedia Pustaka Media

Bambang Widianto dan Iwan Meulia $\mathrm{P}$ (Eds.). 2009. Perspektif budaya. Jakarta: Rajawali Pres.

Bendung Layung Kuning.2011 Atlas Tokohtokoh Wayang dari riwayat hingga silsilah.Yogjakarta : Narasi

Benny Kurniawan . 2012. Ilmu Budaya Dasar. Tangerang Selatan: Jelajah Nusa

Burhan Bungin 2007. Penelitian Kualitatif . Jakarta: Kencana

$\begin{array}{cc}\text { Djama'an dan Aan } & \text { Komariah. } \\ \text { 2012.Metodologi } & \text { Penelitian } \\ \text { Kualitatif Bandung : Alfa Beta }\end{array}$

Edy Setiawati dkk. 2009. Sejarah Kebudayaan Indonesia:Seni Pertunjukkan dan Seni Media .Jakarta : PT Raja Grafindo

Edy Tri Sulistyo. 2005. Kaji Dini Pendidikan Seni. Surakarta: Lembaga Pengembangan Pendidikan dan UPT Penerbitan dan pencerakkan UNS

Emzir.2011. Metodologi Penelitian Kualitatif Analisis Data Jakarta :PT.RajaGranfindo Persada

H.B.Sutopo. 2002. Metodologi Penelitian Kulitataif dasar teori dan terapanya dalam penelitian. Surakarta: Sebelas Maret University Press

H.B.Sutopo. 2006. Metodologi Dasar Teori dan terapanya dalam Peneletian. Surakarta: Sebelas Maret University Press

Hadari Nawawi. 2005. Metode Penelitian Bidang Sosial. Yogyakarta: Gajah Mada University Press
Harsojo. 1982. Pengantar Antropologi . Bandung: Bina Cipta

Hery Lisbijanto. 2013. Wayang .Yogyakarta : Graha Ilmu

Imam Budhi Santoso. 2012. Spiritualisme Jawa : Sejarah, Laku, dan Intisari Ajaran. Yogyakarta: Memayu Publhising

J.Syahban Yasasusastra. 2011. Mengenal Tokoh Wayang Yogjakarta : Pustaka Mahardika

Juju Masunah dan Tati Narawati.2003. Seni dan Pendidikan Seni. Bandung: Pusat Penelitian dan Pengembangan Pendidikkan Seni Tradisional

Lexy J Meoleong. 2004. Metodologi Penelitian Kualitatif. Bandung: Pemaja Rosdakarya

Majalah Liberty.Edisi 2373-11-20 20 April 2009. Jawa Pos

M. Djunaidi Ghony \& Fauzan Almanshur. 2012. Metodologi Penelitian Kualitatif. Jogjakarta: Ar-Ruzz Media

Matthew B. Miles dan Michael Huberman. 1992. Analisis Data Kualitatif Buku Sumber Tentang Metode-metode Baru. Terjemahan Oleh Tjetjep R. Rohidi. Jakarta Universitas Indonesia

Muhammad Teguh .1999. Metodologi Penelitian Ekonomi Teori dan Aplikasi . Jakarta: PT.RajaGranfindo Persada

Nana Syaodih Sukmadinata. 2007. Metode Penelitian Pendidikan. Bandung: PT. Remaja Rosdakarya

Nooryan Bahari .2008.Kritik Seni. Yogjakarta: Pustaka Pelajar 
Proyek Penelitian dan Pencatatan Kebudayaan Daerah. 1980. Eksiklopedia Tari Indonsesia Seri AE. . Jakarta: Departemen Pendidikan dan Kebudayaan

Rohhiman Notowidagdo .2002. Ilmu Budaya Dasar Berdaasarkan Al-Qur'an dan Hadist. Jakarta: PT Raja Grafindo

Rustam E Tamburaka 1999. Pengantar Ilmu Sejarah Teori Filsafat Sejarah, dan Iptek.Jakarta : PT Rineke Cipta

Saifudin Azwar. 2004. Metode Penelitian). Jakarta: Pustaka Pelajar Offset

Soedarsono .1986. Kesenian Bahasa dan Foklor Jawa. Yogjakarta: Proyek Penenlitian dan Pengkajian Kebudayaan Nusantara (Javalogi) Direktorat Jenderal Kebudayaan Departemen Pendidikan dan Kebudyaaan

Soetarno dan Sarwanto. 2010. Wayang Kulit dan Perkembanganya. Solo : ISI Press Solo
Suharsimi Arikunto .2002. Prosedur Penelitian Suatu Pendekatan Praktek edisi revisi v. Jakarta: PT Rineka Cipta

Sugiyono. 2010. Metode Penelitian Pendidikan (Pendekatan Kuantitatif, Kualitatif dan R\&D). Bandung : Alfabeta

Tim Penyusun Kamus Pusat Pembinaan dan Pengembangan Bahasa. 1999. Kamus Besar Bahasa Indonesia Edisi Kedua. Balai Pustaka

Tuti Sumukti. 2006. Semar Dunia Batin Orang Jawa. Yogjakarta: Galangpress

Wiwien Widyawati R 2009. Ensiklopedia Wayang.Yogjakarta : Pura Pustaka 